\title{
Role of paracrine factors in stem and progenitor cell mediated cardiac repair and tissue fibrosis Jana S Burchfield and Stefanie Dimmeler*
}

\author{
Address: Institute of Cardiac Regeneration, Center of Molecular Medicine, University Frankfurt, Theodor Stern Kai, 60590 Frankfurt, Germany \\ Email: Jana S Burchfield - jburchf@yahoo.com; Stefanie Dimmeler* - dimmeler@em.uni-frankfurt.de \\ * Corresponding author
}

Published: 13 October 2008

Fibrogenesis \& Tissue Repair 2008, I:4 doi:10.1 I86/1755-1536-I-4

This article is available from: http://www.fibrogenesis.com/content/l///4

(c) 2008 Burchfield and Dimmeler; licensee BioMed Central Ltd.

This is an Open Access article distributed under the terms of the Creative Commons Attribution License (http://creativecommons.org/licenses/by/2.0), which permits unrestricted use, distribution, and reproduction in any medium, provided the original work is properly cited.
Received: 20 May 2008

Accepted: 13 October 2008

\begin{abstract}
A new era has begun in the treatment of ischemic disease and heart failure. With the discovery that stem cells from diverse organs and tissues, including bone marrow, adipose tissue, umbilical cord blood, and vessel wall, have the potential to improve cardiac function beyond that of conventional pharmacological therapy comes a new field of research aiming at understanding the precise mechanisms of stem cell-mediated cardiac repair. Not only will it be important to determine the most efficacious cell population for cardiac repair, but also whether overlapping, common mechanisms exist. Increasing evidence suggests that one mechanism of action by which cells provide tissue protection and repair may involve paracrine factors, including cytokines and growth factors, released from transplanted stem cells into the surrounding tissue. These paracrine factors have the potential to directly modify the healing process in the heart, including neovascularization, cardiac myocyte apoptosis, inflammation, fibrosis, contractility, bioenergetics, and endogenous repair.
\end{abstract}

\section{Heart failure and stem cells}

Although coronary artery disease accounts for two-thirds of heart failure cases in the United States [1], other causes leading to heart failure are due to non-ischemic events and include myocarditis, hypertension, diabetes, arrhythmias, valvular disease, hypothyroidism, and drug-induced cardiotoxicity. The molecular and cellular mechanisms mediating heart failure have been the focus of numerous research efforts, and include cardiac myocyte apoptosis and necrosis, cardiac myocyte hypertrophy, interstitial fibrosis, decreased contractility, inflammation, oxidative stress, and impaired neovascularization. Pharmacological therapies for the treatment of heart failure have traditionally targeted pump function and quality of life for endstage heart failure patients, and although several medications are available to limit the progression of the disease, the current therapies or interventional procedures do not lead to replacement of tissue and, thus, do not stop or reverse progression of adverse left ventricular (LV) remodeling in all patients $[2,3]$. The use of stem cell-based therapy is becoming increasingly recognized as having the potential to salvage damaged myocardium and to promote endogenous repair of cardiac tissue [4-6]. Although the available data in this area are highly debatable, the potential of stem cell-based therapy for the treatment of heart failure remains an alternative option.

Stem cells are defined as cells that have the capacity to self renew, multipotency/pluriopotency, and clonality, and are divided into embryonic stem cells and adult stem cells. Although embryonic stem cells may have more potential for cardiac differentiation and thus replacement of dam- 
aged myocardium, few studies have focused on paracrine factors released from these cells that may be involved in mediating cardiac repair. Therefore, this review will focus on adult stem or adult progenitor cells, since numerous studies suggest that paracrine factors released from these cells may comprise an important mechanism contributing to cardiac protection after their transplantation into the myocardium.

\section{Types of stem cells}

Adult stem cells comprise at least three different groups: bone marrow-derived stem cells, the circulating pool of stem or progenitor cells, which, at least in part, are derived from the bone marrow, and tissue-resident stem cells. Bone marrow contains a complex assortment of progenitor cells, including hematopoietic stem cells (HSCs), socalled 'side population cells' (SP cells; defined by the expression of the Abcg2 transporter, which enables export of a Hoechst dye) [7], mesenchymal stem cells (MSCs) or stromal cells [8], and multipotential adult progenitor cells (MAPCs), a subset of MSCs [9], (see Table 1).

Another population of progenitor cells that has also been shown to have therapeutic potential is the pool of progenitor cells circulating within the blood. Asahara and Isner isolated the so called 'endothelial progenitor cells' (EPCs), defined by their function to form new blood vessels and enhance neovascularization after ischemia (for a review, see $[10,11]$. However, the definition of these cells has recently been challenged [12] and it appears that these cells, isolated and cultured from the mononuclear cell fraction, may actually consist of a mixture of cells including HSCs, EPCs, and myeloid cells. Regardless of the exact definition of these cell populations, it appears that these cells have the capacity to acquire an endothelial-like phe- notype, or at least, have the capacity to promote neovascularization.

Tissue-resident stem cells in the heart, the 'cardiac stem' cells, include cells characterized by c-Kit ${ }^{+}$marker expression [13], Sca-1+ marker expression [14], cardiac SP cells [15] and cells expressing the protein Islet-1 [16]. Another type of cardiac stem cell has been identified by growing self-adherent clusters (termed 'cardiospheres') from subcultures of murine or human biopsy specimens. Whether these cells and c-Kit ${ }^{+}$, Sca- ${ }^{+}$and cardiac SP cells comprise distinct cell populations is not entirely clear. Furthermore, the exact origin of these $\mathrm{c}-\mathrm{Kit}^{+}, \mathrm{Sca}-1^{+}, \mathrm{SP}$, Islet- ${ }^{+}$, or cardiosphere-derived cardiac stem cells and the mechanisms maintaining the cardiac stem cell pool are unclear. Two recent studies suggest that $\mathrm{c}-\mathrm{Kit}^{+}$and cardiac SP cells may arise from the bone marrow $[17,18]$. However, these studies cannot entirely exclude that specific subpopulations of cardiac stem cells originate from the heart and these cardiac stem cells may represent remnants from embryonic development in selected niches within the heart.

\section{Clinical trials}

Most of the clinical trials using stem/progenitor cells to treat patients following an ischemic event have, to date, used cells derived from the bone marrow [19-22]. Using a systematic review and meta-analysis of all of the completed clinical trials using bone marrow-derived stem cells to treat ischemic heart disease, Abdel-Latif et al. [23] and Lipinski et al. [24] suggested that the transplantation of these cells is safe and efficacious beyond the benefits achieved using traditional therapy using pharmaceuticals. Using such analysis, these studies found that there were decreases in infarct scar size, improvements in ejection fraction, and decreased left ventricular end systolic volume, suggesting improvement in overall global function.

Table I: Summary of cell derived factors in different cell populations.

\begin{tabular}{|c|c|}
\hline Stem cell type & Stem-cell derived factors \\
\hline \multicolumn{2}{|l|}{ Bone marrow } \\
\hline $\mathrm{BM}-\mathrm{MNCs}$ & VEGF, bFGF, Ang-I, IL-I $\beta$, TNF- $\alpha[26]$ \\
\hline BMSCs (HSCs and MSCs) & VEGF, bFGF, IGF, SDF-I, Akt, eNOS [27] \\
\hline MSCs & $\begin{array}{l}\text { VEGF, bFGF, Ang-I, IL-I, SDF-I, PIGF, MCP-I, FGF-7, IL-6, TGF- } \beta \text {, PDGF, PA, MMP- } \\
\text { 9, TB4, Sfrp, Tenacin C, Thrombospondin-I }[28,29]\end{array}$ \\
\hline MAPCs & VEGF, MCP-I, TGF- $\beta$, PDGF-BB [32] \\
\hline Multipotent BM-derived cells (non-HSCs and non-MSCs) & VEGF, bFGF, Ang-I, Ang-2, IGF-I, SDF-I $\alpha$, PDGF-B, HGF [34] \\
\hline \multicolumn{2}{|l|}{ Circulating } \\
\hline Cultured PB-MNCs & VEGF, HGF, G-CSF, GM-CSF [35] \\
\hline EPCs & VEGF-A, VEGF-B, SDF-I, IGF-I [72]; VEGF-A FGF-2, IGF-I, HGF, Ang-I, SDF-I [36] \\
\hline \multicolumn{2}{|l|}{ Tissue resident } \\
\hline \multicolumn{2}{|l|}{ Cardiac stem cells } \\
\hline $\mathrm{c}-\mathrm{kit}^{+}, \mathrm{MDR}-\mathrm{I}^{+}, \mathrm{Sca}-\mathrm{I}^{+}$ & IGF-I, HGF [7I] \\
\hline Adipose stem cells & MMP-9, MMP-3 [82]; VEGF, HGF, TGF- $\beta[83,84]$ \\
\hline
\end{tabular}


Interestingly, these studies found no significant differences in outcomes with the use of less or more than the median number of transplanted stem cells; however, since most of the clinical trials used different cell isolation protocols and subsets of bone marrow-derived cells, it remains unclear which cell subpopulations would have the most beneficial effects [25].

While it is virtually impossible to define the precise mechanisms involved in bone marrow cell-mediated improvement in LV function in patients, the use of animal models of heart disease aids not only in the discovery of which stem cell population is the most efficacious, but also in determining whether there are overlapping or differential mechanisms between stem cell populations, such as the release of paracrine factors. Paracrine factors, such as growth factors and cytokines, are normally released from endogenous cells of the heart in response to injury. These factors may signal via the circulation to mediate stem cell homing from the circulation, bone marrow, or tissue to the site of injury, thus aiding in tissue repair. As a focus of this review, we discuss how exogenously transplanted cells also secrete paracrine factors, which may be more advantageous in mediating cardiac repair by regulating endogenous factors that play direct and important roles in the regulation of neovascularization, fibrosis, inflammation, cardiac myocyte survival, contractility and bioenergetics and endogenous repair.

\section{Cell-derived paracrine factors and neovascularization}

Review of the literature indicates, regardless of whether 'stem' or 'progenitor' cells consist of a mixture of several cell populations or selected subpopulations, that these cells have the capacity to mediate neovascularization. Kamihata et al. [26] have shown that bone marrow mononuclear cells (BM-MNCs), which consist of numerous different types of stem cells, transplanted into ischemic myocardium mediate angiogenesis via increased expression of angiogenic ligands and cytokines such as basic fibroblast growth factor (bFGF), vascular endothelial growth factor (VEGF), angiopoietin-1 (Ang-1), interleukin-1 beta (IL-1 $\beta$ ), and tumor necrosis factor-alpha (TNF- $\alpha$ ). Bone marrow derived stem cells (BMSCs) expressing c-kit and Sca-1 subjected to preconditioning (anoxic conditions) expressed increased amounts of activated Akt and activated eNOS, and secreted higher levels of VEGF, bFGF, insulin growth factor (IGF), and stromal cell derived factor-1 (SDF-1) compared to cells cultured under normal culture conditions, and the myocardial transplantation of these preconditioned cells led to increased blood vessel density [27]. Using MSCs, Kinnaird et al. [28] demonstrated the release of several angiogenic factors, such as VEGF, bFGF, placental growth factor (PIGF), and monocyte chemoattractant protein-1 (MCP$1)$, into the culture media, and the injection of these cells led to an increase in vessel number without MSC incorporation in mature vessels. Using gene expression profiling, additional studies from this laboratory demonstrate that MSCs express bFGF, FGF-7, IL-1, IL-6, PIGF, transforming growth factor-beta (TGF- $\beta$ ), TNF- $\alpha$, and VEGF, which was augmented in response to hypoxia. This increased gene expression paralleled increased secreted protein levels of VEGF, bFGF, IL-6, PIGF, MCP-1, platelet-derived growth factor (PDGF), Ang-1, plasminogen activator (PA), and metalloproteinase-9 (MMP-9) [29]. In the heart, the intramyocardial injection of MSCs led to the in vivo upregulation of bFGF, VEGF, and SDF- $1 \alpha$, and led to increased vessel density after myocardial infarction (MI) [30]. Overexpression of VEGF in MSCs also led to increased capillary density following MI [31], suggesting that stem cells may be modulated to overexpress a variety of key factors that may further enhance their capacity to promote neovascularization in the heart.

Another population of bone marrow-derived stem cells, MAPCs, was also found to secrete factors such as VEGF, MCP-1, PDGF-BB, and TGF- $\beta$, and the authors postulated that this increase in angiogenic factors led to increased vascularity after the intramyocardial injection following MI [32]. Specifically, PDGF-BB and TGF- $\beta$ may act in an autocrine manner on MAPCs to promote their differentiation into a smooth muscle cell-like phenotype [33]. Moreover, a novel clonally expandable population of BMSCs that did not express markers defining MSCs, HSCs, or MAPCs was also capable of secreting paracrine factors such as VEGF, hepatocyte growth factor (HGF), bFGF, PDGF-B, SDF-1 $\alpha$, Ang-1, Ang-2, and IGF-1, leading to therapeutic neovascularization [34].

Other cell types with angiogenic potential are those isolated and cultured from the circulating pool of mononuclear cells, and these cells express factors that are proangiogenic [35]. Specifically, we demonstrated significantly higher mRNA levels of VEGF-A, VEGF-B, SDF-1, and IGF-1 in cultured myeloid EPCs compared to adult endothelial cells, which paralleled significant release of VEGF, SDF-1, and IGF-1 protein into the cell culture supernatant. The paracrine effect of these cells could also be detected in vivo such that, in ischemic limbs, VEGF is also released from recruited human EPCs. As a functional consequence, conditioned medium of EPCs induced a strong migratory response of mature endothelial cells, which was significantly inhibited by VEGF and SDF-1 neutralizing antibodies. Taken together, EPCs exhibit a high expression of angiogenic growth factors that have a direct effect on mature endothelial cell migration and lead to improved neovascularization after ischemia.

Altogether, these studies suggest that several types of bone marrow-derived cells, consisting of either a mixture of dif- 
ferent types of cells, or selected subpopulations of stem cells and circulating progenitor cells, have the capacity to express and secrete paracrine factors that lead to increased neovascularization following ischemia. Although these studies demonstrate an increased release of paracrine factors into the culture media and increased tissue expression of these paracrine factors upon cell transplantation, only some of the studies address whether these paracrine factors are released from the in vivo transplanted cells or whether the transplanted cells modulate endogenous tissue cytokine and growth factor levels. In a recent study, Cho et al. [36], demonstrated that the intramyocardial injection of human EPCs into mice led to the upregulation of a variety of angiogenic and anti-apoptotic factors, such as VEGF-A, FGF-2, IGF-1, HGF, Ang-1, and SDF-1, and these cells led to sustained upregulation of host endogenous factors, such as VEGF-A, FGF-2, Ang-1, Ang2, PIGF, HGF, IGF-1, PDGF-B, and SDF-1, strongly suggesting that these endogenous factors may have contributed to the EPC-induced cardiac protection. Furthermore, Tateno et al. [37], using a hind limb ischemia model, demonstrated using IL-1 $\beta$-deficient mice that the inability of muscle cells to secrete IL- $1 \beta$ reduced induction of angiogenic factors and impaired the neovascularization induced by BM-MNC transplantation. Regardless of whether the effects on elevated perfusion or neovascularization of ischemic tissue are due to paracrine factors from the stem cells themselves or whether these paracrine factors modulate endogenous cells to release factors promoting neovascularization, it is clear that transplanted BMSCs have a vasculogenic capacity and have the ability to improve function. However, it is becoming increasingly clear that the effects of stem cell-derived paracrine factors is not limited to their vasculogenic capacity, but also to their ability to modulate other mechanisms known to be involved in the development of heart failure.

\section{Cell-derived paracrine factors and cardiac myocyte protection}

The protection of the cardiac myocyte from cell death has remained an attractive target for many therapeutic treatments for heart disease. Apoptosis, also known as programmed cell death, and necrosis play major roles in mediating ischemic injury and tissue remodeling. Thus, the possibility that cell therapy leads to protection against death of the cardiac muscle brings a new mechanism of the beneficial effects of stem cell therapy into focus. The measurement of paracrine factors from cultured stem cells as well as enhancement strategies provide evidence that stem cell-derived factors act directly to protect against cardiac myocyte cell death. Specifically, VEGF, bFGF, IGF, and SDF-1 were shown to be secreted by anoxic BMSCs, and the cell supernatants or the transplantation of these cells led to a decrease in cardiac myocyte apoptosis in vitro and in vivo and led to an upregulation of the well-known anti-apoptotic protein Bcl-2 in cardiac myocytes $[27,38]$. Furthermore, the overexpression of some of these factors in the heart has further substantiated their protective role in the heart after injury. For example, the intramyocardial injection of adenoviruses overexpressing VEGF led to decreased infarct size and increased expression of Bcl-2 [39], and injection of human recombinant bFGF also prevented ischemia-induced myocardial death and increased expression of $\mathrm{Bcl}-2$ [40]. In addition, enhancement strategies targeted at improving the in vivo survival of the stem cells themselves has also proven to decrease cardiac myocyte death via the secretion of paracrine factors. The overexpression of the survival protein Akt in MSCs led to a decrease in cardiac myocyte apoptosis in vitro and their myocardial transplantation led to a decrease in infarct size [41-44]. In addition to secreting VEGF, bFGF, IGF, and SDF-1, Akt-overexpressing MSCs also secrete HGF, thymosin $\beta 4$ (TB4), and secreted frizzled related protein 2 (Sfrp2) [45]. HGF has been shown to be protective in acute MI [46], and specifically anti-apoptotic, as shown by HGF gene transfer [47], intravenous HGF treatment [48], or its overexpression in transplanted MSCs [44]. TB4, a Gactin sequestering peptide, was also shown to directly promote survival of embryonic and postnatal cardiac myocytes in culture, and after coronary artery ligation in mice, TB4 treatment resulted in enhanced myocardial survival [49]. Sfrp2 released from Akt-overexpressing MSCs also leads to a decrease in cell death of isolated hypoxic cardiac myocytes in culture and specifically blocks the pro-apoptotic effects of Wnt3a [45].

Altogether, these studies demonstrate that paracrine factors from exogenously transplanted BMSCs expressing ckit and Sca-1, or transplanted MSCs aid in prevention of cardiac myocyte cell death and, thus, in the preservation of muscle mass. However, the exact molecular pathways leading to this protection are not well defined and are likely to involve modulation of both caspase-dependent and caspase-independent pathways of cell death. This additionally discovered benefit of stem cell therapy for the treatment of the heart following injury may not be limited to cardiac myocyte protection. Since myocardial injury leads to an infiltration of inflammatory cells and upregulation of cytokines, stem cell therapy may additionally target these pathways involved in pathophysiological remodeling.

\section{Cell-derived paracrine factors and inflammation}

There are two forms of immunity, innate and adaptive. Innate immune responses are phylogenetically conserved and initiate a quick response against a pathogen or myocardial injury, whereas adaptive immune responses involve antigen recognition and subsequent antibody generation. The regulation of these two types of immune responses in the heart involves upregulation and interac- 
tion of pro-inflammatory and anti-inflammatory cytokines. In response to stress, the heart increases expression of a variety of pro-inflammatory and anti-inflammatory cytokines, which play a dual role in the heart. Initial inflammatory cytokine expression is necessary for maintaining homeostatic responses within the heart after stress or injury; however, the dysregulation and sustained upregulation of certain cytokines ultimately leads to adverse remodelling and heart failure [50]. The specific regulation of expression and concentration of both proinflammatory and anti-inflammatory cytokines and their specific interactions is complex and incompletely understood in the heart, but may comprise a mechanism underlying the beneficial effects of stem cell therapy. There is increasing evidence that stem cells themselves, specifically MSCs, secrete a variety of pro-inflammatory and antiinflammatory cytokines and that these cytokines may directly act to limit deleterious, sustained endogenous inflammation in the heart. Thus, administration of MSCs led to a downregulation of the cytokines TNF- $\alpha$, IL- $1 \beta$ and IL-6, which are known to be involved in adverse LV remodelling [51]. Furthermore, the transplantation of MSCs attenuated myocardial dysfunction in a rat model of acute myocarditis [52]. Specifically, the authors demonstrated that MSC transplantation led to a decrease in CD68-positive inflammatory cells and decreased MCP-1 expression. Furthermore, the MSC-derived conditioned media protected isolated adult rat cardiac myocytes from MCP-1-induced injury, suggesting that the anti-inflammatory effects were due to paracrine factors released from these stem cells. Clearly, MSCs seem to possess antiinflammatory properties, specifically through cytokine expression and infiltration of inflammatory cells, but these effects may not influence all aspects of innate immunity. The infiltration of neutrophils after MI, as measured by myeloid peroxidise (MPO) activity, did not appear to differ between intramyocardially transplanted singly cloned MSCs, unselected MSCs, BM-MNCs, or peripheral blood mononuclear cells (PBMNCs) [53]. While most studies focused on defining the role of adaptive immunity in the heart use models of autoimmune myocarditis or organ transplantation, it is becoming increasingly clear that $\mathrm{T}$ lymphocytes play a role in MI. Specifically, VardaBloom et al. [54] have shown that infiltration of T lymphocytes into the heart following MI, and in vitro co-culture of T lymphocytes from post-MI rats with isolated cardiac myocytes from a non-infarcted rat heart resulted in cytotoxicity of the cardiac myocytes. Accordingly, it is well established that MSCs play a role in suppressing adaptive immune responses. Specifically, MSCs suppressed T lymphocyte proliferation and MSCs co-cultured with purified subpopulations of immune cells altered cytokine secretion and induced a more anti-inflammatory phenotype $[55,56]$. It is clear that MSCs have a direct immunomodulatory role in the adaptive immune response, but the entire story of whether this immunomodulation occurs in the heart after MSC transplantation is far from complete; also, whether other stem cell populations play an immunomodulatory role in the heart has not been tested. These cells may directly modulate $\mathrm{T}$ lymphocyte function in the heart, leading to either protection against their cytotoxicity or, alternatively, modulation of their role in cardiac remodelling. Specifically, $\mathrm{T}$ lymphocytes co-cultured with cardiac fibroblasts led to an increase in cardiac fibroblast pro-collagen expression [57], suggesting that the in vivo suppression of $\mathrm{T}$ lymphocyte accumulation or function may also inhibit myocardial fibrosis. Thus, alterations in the innate and adaptive immune responses in the heart by transplanted stem cells may serve as another mechanism contributing to the improvement in LV function and the attenuation of adverse $\mathrm{LV}$ remodelling.

\section{Cell-derived paracrine factors and fibrosis}

Most of the studies using stem cell therapy after MI have shown a reduction in fibrosis. However, in most studies it was not clearly defined whether the decreased fibrosis was simply due to replacement of dead myocardium or whether the paracrine factors released from these different subpopulations of stem cells may have had direct effects on the extracellular matrix. Nevertheless, in one study, a direct effect on fibrosis by stem cells was demonstrated; MSC-conditioned medium significantly attenuated proliferation of cardiac fibroblasts and upregulated elastin, myocardin and DNA-damage inducible transcript 3 [58]. Furthermore, MSC-conditioned medium significantly downregulated type I and III collagen expression, and significantly suppressed type III collagen promoter activity [58]. In a subsequent study, the intravenous injection of human multipotent stromal cells led to decreased fibrosis, and gene expression analysis of cultured cells revealed an upregulation of several matrix-modulating factors, such as matrix metalloproteinase-2 (MMP-2), tissue inhibitors of matrix metalloproteinases (TIMP)-1 and TIMP-2, and the matricellular proteins thrombospondin-1 and tenacin C, suggesting that these cells may have a direct effect on extracellular matrix remodeling [59]. Importantly, transplantation of MSCs led to decreased fibrosis in a rat model of dilated cardiomyopathy [60]. Specifically, the transplantation of these cells decreased MMP-2 and MMP-9 protein expression. Several paracrine factors released from stem cells, such as HGF, adrenomedullin (AM), TB4, and IL-1 $\beta$, have previously been shown to directly reduce cardiac fibrosis. For example, adenovirus-mediated HGF gene transfer before ischemia led to decreased fibrosis [47], and treatment of dilated cardiomyopathic Syrian hamsters with HGF for three weeks suppressed cardiac fibrosis and led to a decrease in TGF- $\beta 1$ and type I collagen expression [61]. AM administration also inhibited LV remodeling in heart failure [62] and specifically inhibited 
the proliferation of cardiac fibroblasts through a cAMPdependent pathway [63]. TB4, harboring collagenase activity, has been shown to be important in cardiac healing after MI, and these effects may be mediated by its derivative, N-acetyl-seryl-aspartyl-lysyl-proline (AcSDKP). Ac-SDKP was reported to reduce LV fibrosis in hypertensive rats, reverse fibrosis and have collagenase activity, similar to TB4 [64]. IL-1 $\beta$, also secreted from several populations of stem cells, has a direct anti-proliferative effect on cardiac fibroblasts [65]. Not only do the paracrine factors released from MSCs modulate myocardial fibrosis, but also cytokine or growth factor preconditioning of these MSCs leads suppression of fibrosis. For example, myocardially transplanted MSCs preconditioned with SDF-1 led to a decrease in fibrosis after 4 weeks MI which was abrogated using a CXCR4 antagonist [66]Moreover, the intramyocardial injection of TGF- $\beta$ pretreated CD117+ cells led to a decrease in collagen fiber accumulation in the infarcted region [67]. Altogether, these studies suggest that stem cell-derived paracrine factors play a role in extracellular matrix remodeling that may contribute to the observed improvements in LV function after stem cell transplantation.

\section{Cell-derived paracrine factors and contractility and bioenergetics}

Although few studies have investigated a direct role of bone marrow-derived cells on cardiac myocyte contractility and bioenergetic function, it is becoming increasingly clear that paracrine factors may act via this mechanism. In one study, the intravenous injection of MSCs preserved LV systolic function after MI without decreasing infarct size, suggesting that, in this case, MSCs did not protect against cardiac myocyte death but may have had a more direct effect on cardiac myocyte contractility [68]. Furthermore, incubation of supernatants from BM-MNCs with isolated adult cardiac myocytes cultured for 72 hours led to an increase in fractional shortening, the maximal rate of relengthening, the maximal rate of shortening, and the amplitude of the calcium ratio of the individual myocytes, suggesting that paracrine factors released from stem cells have a direct effect on the preservation of cardiac myocyte contractile capacity. This is further substantiated by an investigation determining whether myocardial stem cell transplantation leads to changes in enzymes that modulate intracellular calcium and mediate cardiac myocyte contraction. Using a population of heart-derived stem cells expressing Sca-1 but lacking CD31, it was shown that the intramyocardial injection of these cells following MI led to a higher phosphocreatine/ATP ratio compared to non-stem cell-treated hearts and higher creatine kinase$\mathrm{mt}$, creatine kinase- $\mathrm{m}$, and mitochondrial ATPase- $\beta$, suggesting improved bioenergetic characteristics [69]. Furthermore, the intramyocardial injection of a stock of swine multipotent adult progenitor cells ('pMultistem cells') led to a recovery of border zone subendocardial phosphocreatine/ATP ratios and increased expression of creatine kinase-mt and creatine kinase-m isoforms after MI [70]. Altogether, these studies suggest that bone marrow-derived cells have the capacity to modulate calcium handling, and preserve cardiac contractility and bioenergetics. Whether these improvements directly limit structural and contractile abnormalities in heart disease or whether these improvements occur in parallel with, or in addition to, other stem cell-mediated beneficial effects remains to be determined.

\section{Cell-derived paracrine factors and endogenous repair}

Another mechanism of cell therapy includes the ability of transplanted cells to promote endogenous repair, which may include modulation of cardiac-resident stem cells and epicardial progenitor cells by specifically regulating endogenous or stem cell-derived paracrine factors. One study demonstrated that cardiac stem cells and early committed cells expressing c-kit, MDR1, and Sca-1 express cMet and IGF-1 receptors and synthesize and secrete corresponding ligands, HGF and IGF-1, suggesting that these factors may act in an autocrine manner to regulate the functionality of these cells [71]. Furthermore, since these cells express receptors for HGF and IGF-1, it is possible that paracrine factors secreted from transplanted BMSCs into the myocardium or transplanted circulating bloodderived progenitor cells may regulate the functionality of these cardiac resident stem cells, thereby leading to cardiac repair and protection. Consistent with this hypothesis, supernatants of myeloid EPCs were shown to induce migration of cardiac stem cells [72]. These preliminary data suggest that a complex cross-talk may exist between transplanted stem cells and the endogenous cardiac cell pool. The delineation of these pathways will be important for the future of stem cell therapy in heart failure.

\section{Paracrine factors from non-bone marrow derived stem cells}

Stem cells from sources other than those derived from bone marrow are also the subject of numerous investigations. For example, mesenchymal stem cells can also be isolated from adipose tissue [73], muscle [74], umbilical cord blood [75], and a variety of other tissues [76-80]. It has also been suggested that MSCs can be found in all post-mitotic organs and tissues, including vessel walls [81]. It is not entirely clear whether these cells function identically in improving cardiac performance to MSCs derived from the bone marrow. Using a hind limb ischemia model, one study suggested that MSCs isolated from adipose tissue have a greater angiogenic capacity than MSCs isolated from bone marrow [82], and these cells had higher expression levels of MMP-3 and MMP-9. Alternatively, these cells, derived from either adipose tissue or bone marrow, have similar capacities to secrete 
paracrine factors. Cultured adipose derived stem cells (ASCs) secrete large amounts of VEGF, HGF, and TGF- $\beta$, and high levels of VEGF when subjected to hypoxic conditions. The conditioned media from hypoxic ASCs significantly increased endothelial cell growth and reduced endothelial cell apoptosis, and transplantation of these cells into ischemic hind limbs led to improved perfusion, suggesting paracrine factors from these cells promote neovascularization [83]. Interestingly, the ability of ASCs to promote survival, proliferation, and migration of mature and progenitor endothelial cells in vitro and to promote reperfusion in a mouse hind limb ischemia model appears to be dependent on HGF [84]. In the heart, the transplantation of adult progenitor cells derived from either adipose tissue or bone marrow led to a decrease in myocardial pro-inflammatory and pro-apoptotic signaling and, thus, to cardiac protection against ischemia [85]. As researchers continue to study and compare stem cells from diverse organs and tissues, it will become evident whether overlapping or divergent mechanisms exist between these cells, and which paracrine factors are released from cells. These ongoing studies will prove beneficial in identifying which cell type may be optimal for the treatment of ischemic diseases and, ultimately, for the treatment of heart failure.

\section{Conclusion}

Paracrine factors from stem cells transplanted into the myocardium play an important role in modulating LV remodeling after an ischemic injury. It should be noted that the evidence supporting this idea is based on numerous studies in animal models. The contribution of the paracrine effects in clinical trials (compared to cell intrinsic functions) cannot be exactly determined as long as autologous cells are implanted and the availability of tissue restricts information on local cytokine production. However, the clinically used cell populations, namely total bone marrow nuclear cells $[26,86]$, cultured endothelial progenitor cells [36,72], and MSCs [28,29,4145 ], were all shown to release paracrine factors when transplanted into ischemia models. In the future, not only will it be important to determine which paracrine factors are up- or down-regulated, but also to characterize the spatio-temporal release and the local concentrations produced by the injected or infused cell populations. Furthermore, an understanding of synergistic or additive interactions between these factors is crucial, as well as of whether these factors act on one or a combination of mechanisms that lead to heart failure. This may ultimately lead to the generation of pharmacological agents that can be used to treat heart failure, possibly negating the need for cell-based therapy altogether, (see Figure 1).

\section{Competing interests}

The authors declare that they have no competing interests.

\section{Authors' contributions}

JB drafted the review. SD conceived, designed, drafted, and edited the review.

\section{Acknowledgements}

This work was supported by a grant from the Leducq Foundation to S Dimmeler.

\section{References}

I. Gheorghiade M, Bonow RO: Chronic heart failure in the United States: a manifestation of coronary artery disease. Circulation 1998, 97:282-289.

2. Mann DL, Bristow MR: Mechanisms and models in heart failure: the biomechanical model and beyond. Circulation 2005, II I:2837-2849.

3. Massie BM: $\mathbf{1 5}$ years of heart-failure trials: what have we learned? Lancet 1998, 352(Suppl I):SI29-33.

4. Leri A, Kajstura J, Anversa P: Cardiac stem cells and mechanisms of myocardial regeneration. Physiol Rev 2005, 85: I373-1416.

5. Mazhari R, Hare JM: Mechanisms of action of mesenchymal stem cells in cardiac repair: potential influences on the cardiac stem cell niche. Nat Clin Pract Cardiovasc Med 2007, 4(Suppl I):S2I-26.

6. Rosenthal N, Santini MP, Musaro A: Growth factor enhancement of cardiac regeneration. Cell Transplant 2006, I5(SuppI I):S4I-45.

7. Jackson KA, Majka SM, Wang H, Pocius J, Hartley CJ, Majesky MW, Entman ML, Michael LH, Hirschi KK, Goodell MA: Regeneration of ischemic cardiac muscle and vascular endothelium by adult stem cells. J Clin Invest 2001, 107:1395-1402.

8. Toma C, Pittenger MF, Cahill KS, Byrne BJ, Kessler PD: Human mesenchymal stem cells differentiate to a cardiomyocyte phenotype in the adult murine heart. Circulation 2002, 105:93-98.

9. Jiang $Y$, Jahagirdar BN, Reinhardt RL, Schwartz RE, Keene CD, OrtizGonzalez XR, Reyes M, Lenvik T, Lund T, Blackstad M, Du J, Aldrich S, Lisberg A, Low WC, Largaespada DA, Verfaillie CM: Pluripotency of mesenchymal stem cells derived from adult marrow. Nature 2002, 41 8:41-49.

10. Urbich C, Dimmeler S: Endothelial progenitor cells: characterization and role in vascular biology. Circ Res 2004, 95:343-353.

II. Rafii S, Lyden D: Therapeutic stem and progenitor cell transplantation for organ vascularization and regeneration. Nat Med 2003, 9:702-7/2.

12. Case J, Mead LE, Bessler WK, Prater D, White HA, Saadatzadeh MR, Bhavsar JR, Yoder MC, Haneline LS, Ingram DA: Human CD34+ACI33+VEGFR-2+ cells are not endothelial progenitor cells but distinct, primitive hematopoietic progenitors. Exp Hematol 2007, 35: I 109-I I 18.

13. Beltrami AP, Barlucchi L, Torella D, Baker M, Limana F, Chimenti S, Kasahara H, Rota M, Musso E, Urbanek K, Leri A, Kajstura J, NadalGinard B, Anversa P: Adult cardiac stem cells are multipotent and support myocardial regeneration. Cell 2003, I I 4:763-776.

14. Oh H, Bradfute SB, Gallardo TD, Nakamura T, Gaussin V, Mishina Y, Pocius J, Michael LH, Behringer RR, Garry DJ, Entman ML, Schneider MD: Cardiac progenitor cells from adult myocardium: homing, differentiation, and fusion after infarction. Proc Natl Acad Sci USA 2003, 100:12313-12318.

15. Hierlihy AM, Seale P, Lobe CG, Rudnicki MA, Megeney LA: The post-natal heart contains a myocardial stem cell population. FEBS Lett 2002, 530:239-243.

16. Laugwitz KL, Moretti A, Lam J, Gruber P, Chen Y, Woodard S, Lin LZ, Cai CL, Lu MM, Reth M, Platoshyn O, Yuan JX, Evans S, Chien KR: Postnatal isI I+ cardioblasts enter fully differentiated cardiomyocyte lineages. Nature 2005, 433:647-653.

17. Fazel S, Cimini M, Chen L, Li S, Angoulvant D, Fedak P, Verma S, Weisel RD, Keating A, Li RK: Cardioprotective c-kit+ cells are from the bone marrow and regulate the myocardial balance of angiogenic cytokines. J Clin Invest 2006, I I 6: I 865-I877.

18. Mouquet F, Pfister O, Jain M, Oikonomopoulos A, Ngoy S, Summer $R$, Fine $A$, Liao R: Restoration of cardiac progenitor cells after myocardial infarction by self-proliferation and selective 


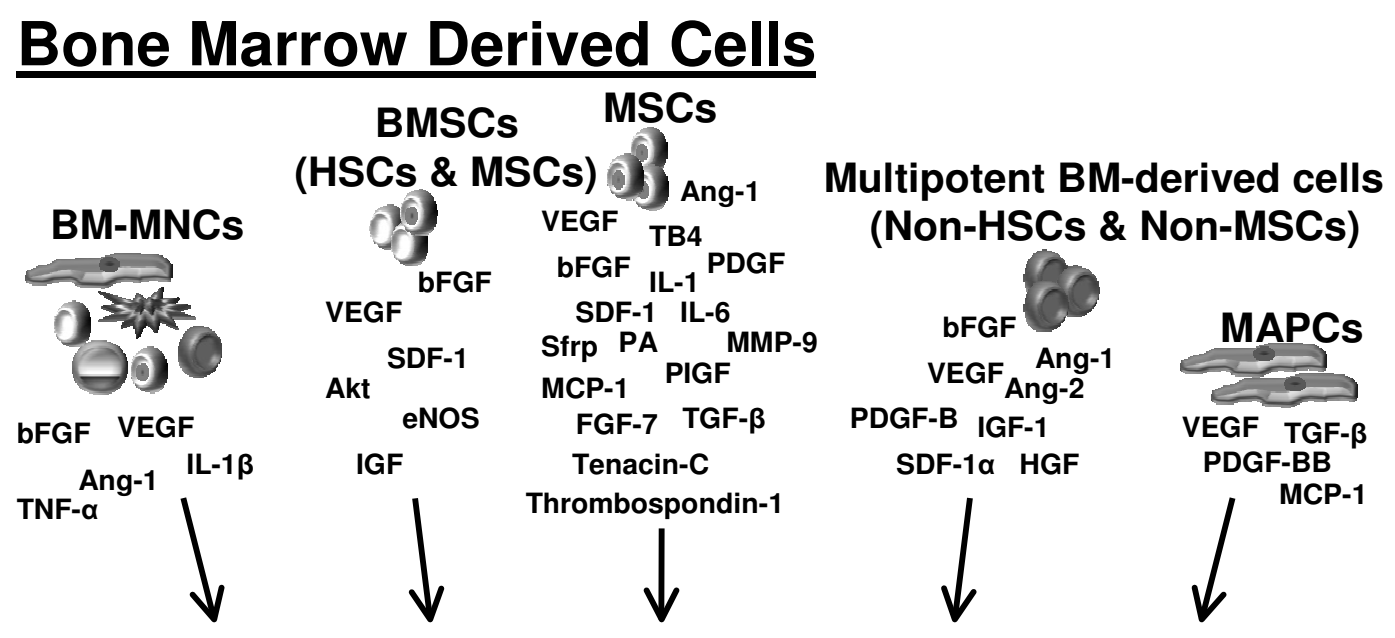

\section{Factors Upregulated in Endogenous Cardiac \\ VEGF-A PIGF \\ FGF-2 \\ Ang-1 \\ Ang-2 \\ HGF \\ IGF-1 \\ PDGF-B \\ SDF-1

$\begin{array}{ll}\text { IL-1 } \beta & \text { Bax } \\ \text { MCP-1 } & \text { Bcl-2 } \\ \text { TNF- } \alpha & \end{array}$

Elastin Type I collagen
Myocardin Type 3 collagen
DNA-damage
inducible
transcript 3 \\ Phosphocreatine \\ ATP \\ Creatine kinases \\ Mito ATPase- $\beta$}

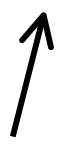

GM-CSF

G-CSF

VEGF HGF

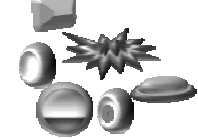

PB-MNCs

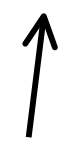

FGF-2 HGF

IGF-1

SDF-1 Ang-1

VEGF-B

VEGF-A

SDF-1

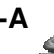

1

VEGF

MMP-3

HGF

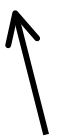

HGF

IGF-1

MMP-9

TGF- $\beta$

(c-kit ${ }^{+}$, MDR-1+,Sca-

CSCs

\section{Adipose-derived MSCs}

Circulating Progenitor Cells Tissue Resident Stem Cells

Key: BM-MNCs=bone marrow mononuclear cells; BMSCs=bone marrow stem cells; HSCs=hematopoietic stem cells;

MSCs=mesenchymal stem cells; MAPCs= multipotential adult progenitor cells; PB-MNCs=peripheral blood mononuclear cells;

EPCs=endothelial progenitor cells; CSCs=cardiac stem cells; VEGF=vascular endothelial growth factor; FGF=fibroblast growth factor; Ang=angiopoietin; PIGF=placental growth factor; HGF=hepatocyte growth factor; IGF=insulin growth factor; PDGF=platelet-derived

growth factor; SDF=stromal cell-derived factor; IL=interleukin; MCP-1=monocyte chemoattractant protein-1;TNF=tumor necrosis factor;

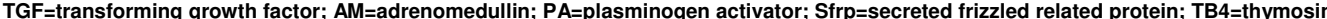

beta 4; MMP=matrix metalloproteinase;TIMP=tissue inhibitors of matrix metalloproteinases

Figure I (see legend on next page) 
Figure I (see previous page)

Actions of stem cell derived paracrine factors on the heart. Stem cells transplanted into the myocardium release numerous factors that may act in an autocrine manner or paracrine manner to modulate the implanted cells themselves, or the endogenous cells of the heart, including cardiac myocytes, fibroblasts, endothelial cells, vascular smooth muscle cells, and cardiac stem cells. These factors include a variety of growth factors, cytokines, and extracellular matrix proteins that may lead to upregulation of several endogenous growth factors, cytokines, and extracellular matrix proteins, thereby tightly regulating neovascularization, protection against cell death, inflammation, fibrosis, contractility, bioenergetics, and endogenous repair. Regulation of these processes, either singly or in combination, by stem cell transplantation ultimately leads to improvement in left ventricular function following myocardial infarction. Future research in discovering novel stem-derived paracrine factors and their precise mechanistic roles in heart repair and fibrosis may ultimately lead to the generation of novel therapeutic agents for the treatment of heart failure.

homing of bone marrow-derived stem cells. Circ Res 2005, 97:1090-1092.

19. Schächinger V, Erbs S, Elsässer A, Haberbosch W, Hambrecht R, Hölschermann H, Yu J, Corti R, Mathey DG, Hamm CW, Süselbeck T, Assmus B, Tonn T, Dimmeler S, Zeiher AM, REPAIR-AMI Investigators: Intracoronary bone marrow-derived progenitor cells in acute myocardial infarction. N Engl J Med 2006, 355: $1210-1221$.

20. Wollert KC, Meyer GP, Lotz J, Ringes-Lichtenberg S, Lippolt P, Breidenbach C, Fichtner S, Korte T, Hornig B, Messinger D, Arseniev L, Hertenstein B, Ganser A, Drexler H: Intracoronary autologous bone-marrow cell transfer after myocardial infarction: the BOOST randomised controlled clinical trial. Lancet 2004, 364: $|4|-\mid 48$.

21. Perin EC, Dohmann HF, Borojevic R, Silva SA, Sousa AL, Mesquita CT, Rossi MI, Carvalho AC, Dutra HS, Dohmann HJ, Silva GV, Belém L, Vivacqua R, Rangel FO, Esporcatte R, Geng YJ, Vaughn WK, Assad JA, Mesquita ET, Willerson JT: Transendocardial, autologous bone marrow cell transplantation for severe, chronic ischemic heart failure. Circulation 2003, 107:2294-2302.

22. Dimmeler S, Burchfield J, Zeiher AM: Cell-based therapy of myocardial infarction. Arterioscler Thromb Vasc Biol 2008, 28:208-2I6.

23. Abdel-Latif A, Bolli R, Tleyjeh IM, Montori VM, Perin EC, Hornung CA, Zuba-Surma EK, AI-Mallah M, Dawn B: Adult bone marrowderived cells for cardiac repair: a systematic review and meta-analysis. Arch Intern Med 2007, 167:989-997.

24. Lipinski MJ, Biondi-Zoccai GG, Abbate A, Khianey R, Sheiban I, Bartunek J, Vanderheyden M, Kim HS, Kang HJ, Strauer BE, Vetrovec GW: Impact of intracoronary cell therapy on left ventricular function in the setting of acute myocardial infarction: a collaborative systematic review and meta-analysis of controlled clinical trials. J Am Coll Cardiol 2007, 50:176I-1767.

25. Seeger FH, Tonn T, Krzossok N, Zeiher AM, Dimmeler S: Cell isolation procedures matter: a comparison of different isolation protocols of bone marrow mononuclear cells used for cell therapy in patients with acute myocardial infarction. Eur Heart $\int 2007$, 28:766-772.

26. Kamihata $H$, Matsubara $H$, Nishiue $T$, Fujiyama $S$, Tsutsumi $Y$, Ozono R, Masaki H, Mori Y, Iba O, Tateishi E, Kosaki A, Shintani S, Murohara T, Imaizumi T, Iwasaka T: Implantation of bone marrow mononuclear cells into ischemic myocardium enhances collateral perfusion and regional function via side supply of angioblasts, angiogenic ligands, and cytokines. Circulation 2001, 104: 1046-1052.

27. Uemura R, Xu M, Ahmad N, Ashraf M: Bone marrow stem cells prevent left ventricular remodeling of ischemic heart through paracrine signaling. Circ Res 2006, 98: I4I4-I42I.

28. Kinnaird T, Stabile E, Burnett MS, Shou M, Lee CW, Barr S, Fuchs S, Epstein SE: Local delivery of marrow-derived stromal cells augments collateral perfusion through paracrine mechanisms. Circulation 2004, 109:1543-1549.

29. Kinnaird T, Stabile E, Burnett MS, Lee CW, Barr S, Fuchs S, Epstein SE: Marrow-derived stromal cells express genes encoding a broad spectrum of arteriogenic cytokines and promote in vitro and in vivo arteriogenesis through paracrine mechanisms. Circ Res 2004, 94:678-685.

30. Tang YL, Zhao Q, Qin X, Shen L, Cheng L, Ge J, Phillips MI: Paracrine action enhances the effects of autologous mesenchy- mal stem cell transplantation on vascular regeneration in rat model of myocardial infarction. Ann Thorac Surg 2005, 80:229-236. discussion 236-227.

3I. Matsumoto R, Omura T, Yoshiyama M, Hayashi T, Inamoto S, Koh KR, Ohta K, Izumi Y, Nakamura Y, Akioka K, Kitaura Y, Takeuchi K, Yoshikawa J: Vascular endothelial growth factor-expressing mesenchymal stem cell transplantation for the treatment of acute myocardial infarction. Arterioscler Thromb Vasc Biol 2005, 25: II68-II 173 .

32. Pelacho B, Nakamura $Y$, Zhang J, Ross J, Heremans $Y$, Nelson-Holte M, Lemke B, Hagenbrock J, Jiang Y, Prosper F, Luttun A, Verfaillie CM: Multipotent adult progenitor cell transplantation increases vascularity and improves left ventricular function after myocardial infarction. J Tissue Eng Regen Med 2007, I:5 I-59.

33. Ross JJ, Hong Z, Willenbring B, Zeng L, Isenberg B, Lee EH, Reyes M, Keirstead SA, Weir EK, Tranquillo RT, Verfaillie CM: Cytokineinduced differentiation of multipotent adult progenitor cells into functional smooth muscle cells. J Clin Invest 2006, I | 6:3139-3|49.

34. Yoon YS, Wecker A, Heyd L, Park JS, Tkebuchava T, Kusano K, Hanley A, Scadova H, Qin G, Cha DH, Johnson KL, Aikawa R, Asahara T, Losordo DW: Clonally expanded novel multipotent stem cells from human bone marrow regenerate myocardium after myocardial infarction. J Clin Invest 2005, I I 5:326-338.

35. Rehman J, Li J, Orschell CM, March KL: Peripheral blood "endothelial progenitor cells" are derived from monocytel macrophages and secrete angiogenic growth factors. Circulation 2003, 107: II64-II69.

36. Cho HJ, Lee N, Lee JY, Choi YJ, li M, Wecker A, Jeong JO, Curry C, Qin G, Yoon YS: Role of host tissues for sustained humoral effects after endothelial progenitor cell transplantation into the ischemic heart. J Exp Med 2007, 204:3257-3269.

37. Tateno K, Minamino T, Toko H, Akazawa H, Shimizu N, Takeda $\mathrm{S}$, Kunieda T, Miyauchi H, Oyama T, Matsuura K, Nishi J, Kobayashi Y, Nagai T, Kuwabara Y, Iwakura Y, Nomura F, Saito Y, Komuro I: Critical roles of muscle-secreted angiogenic factors in therapeutic neovascularization. Circ Res 2006, 98: I I 94-I 202.

38. Xu M, Uemura R, Dai $Y$, Wang $Y$, Pasha $Z$, Ashraf M: In vitro and in vivo effects of bone marrow stem cells on cardiac structure and function. J Mol Cell Cardiol 2007, 42:44I-448.

39. Zhou L, Ma W, Yang Z, Zhang F, Lu L, Ding Z, Ding B, Ha T, Gao X, $\mathrm{Li} C$ : VEGFI65 and angiopoietin-I decreased myocardium infarct size through phosphatidylinositol-3 kinase and $\mathrm{Bcl}-2$ pathways. Gene Ther 2005, 12:196-202.

40. Nishida S, Nagamine H, Tanaka Y, Watanabe G: Protective effect of basic fibroblast growth factor against myocyte death and arrhythmias in acute myocardial infarction in rats. Circ J 2003, 67:334-339

4I. Mangi AA, Noiseux N, Kong D, He H, Rezvani M, Ingwall JS, Dzau V] Mesenchymal stem cells modified with Akt prevent remodeling and restore performance of infarcted hearts. Nat Med 2003, 9:1195-1201.

42. Gnecchi M, He H, Liang OD, Melo LG, Morello F, Mu H, Noiseux N, Zhang L, Pratt RE, Ingwall JS, Dzau VJ: Paracrine action accounts for marked protection of ischemic heart by Akt-modified mesenchymal stem cells. Nat Med 2005, I I:367-368.

43. Gnecchi M, He H, Noiseux N, Liang OD, Zhang L, Morello F, Mu H, Melo LG, Pratt RE, Ingwall JS, Dzau VJ: Evidence supporting para- 
crine hypothesis for Akt-modified mesenchymal stem cellmediated cardiac protection and functional improvement. FASEB J 2006, 20:661-669.

44. Guo Y, He J, Wu J, Yang L, Dai S, Tan X, Liang L: Locally overexpressing hepatocyte growth factor prevents post-ischemic heart failure by inhibition of apoptosis via calcineurin-mediated pathway and angiogenesis. Arch Med Res 2008, 39: I79- I88.

45. Mirotsou M, Zhang Z, Deb A, Zhang L, Gnecchi M, Noiseux N, Mu H, Pachori A, Dzau V: Secreted frizzled related protein 2 (Sfrp2) is the key Akt-mesenchymal stem cell-released paracrine factor mediating myocardial survival and repair. Proc Nat Acad Sci USA 2007, 104:1643-1648.

46. Aoki M, Morishita R, Taniyama Y, Kida I, Moriguchi A, Matsumoto K, Nakamura T, Kaneda Y, Higaki J, Ogihara T: Angiogenesis induced by hepatocyte growth factor in non-infarcted myocardium and infarcted myocardium: up-regulation of essential transcription factor for angiogenesis, ets. Gene Ther 2000, 7:417-427.

47. Chen XH, Minatoguchi S, Kosai K, Yuge K, Takahashi T, Arai M, Wang N, Misao Y, Lu C, Onogi H, Kobayashi H, Yasuda S, Ezaki M, Ushikoshi $H$, Takemura $G$, Fujiwara $T$, Fujiwara $H$ : In vivo hepatocyte growth factor gene transfer reduces myocardial ischemiareperfusion injury through its multiple actions. I Card Fail 2007, 13:874-883

48. Wang Y, Ahmad N, Wani MA, Ashraf M: Hepatocyte growth factor prevents ventricular remodeling and dysfunction in mice via Akt pathway and angiogenesis. J Mol Cell Cardiol 2004, 37: 104I-1052

49. Bock-Marquette I, Saxena A, White MD, Dimaio JM, Srivastava D: Thymosin beta4 activates integrin-linked kinase and promotes cardiac cell migration, survival and cardiac repair. Nature 2004, 432:466-472.

50. Wilson EM, Diwan A, Spinale FG, Mann DL: Duality of innate stress responses in cardiac injury, repair, and remodeling. Mol Cell Cardiol 2004, 37:80 I-8I I.

51. Guo J, Lin GS, Bao CY, Hu ZM, Hu MY: Anti-inflammation role for mesenchymal stem cells transplantation in myocardia infarction. Inflammation 2007, 30:97-104.

52. Ohnishi S, Yanagawa B, Tanaka K, Miyahara Y, Obata H, Kataoka M, Kodama M, Ishibashi-Ueda H, Kangawa K, Kitamura S, Nagaya $\mathrm{N}$ : Transplantation of mesenchymal stem cells attenuates myocardial injury and dysfunction in a rat model of acute myocarditis. J Mol Cell Cardiol 2007, 42:88-97.

53. Zhang S, Ge J, Sun A, Xu D, Qian J, Lin J, Zhao Y, Hu H, Li Y, Wang $\mathrm{K}$, Zou $Y$ : Comparison of various kinds of bone marrow stem cells for the repair of infarcted myocardium: single clonally purified non-hematopoietic mesenchymal stem cells serve as a superior source. | Cell Biochem 2006, 99: | I32-I | 47.

54. Varda-Bloom N, Leor J, Ohad DG, Hasin Y, Amar M, Fixler R, Battler A. Eldar M, Hasin D: Cytotoxic T lymphocytes are activated following myocardial infarction and can recognize and kil healthy myocytes in vitro. J Mol Cell Cardiol 2000, 32:2 I4 I-2 I 49

55. Di Nicola M, Carlo-Stella C, Magni M, Milanesi M, Longoni PD, Matteucci P, Grisanti S, Gianni AM: Human bone marrow stromal cells suppress T-lymphocyte proliferation induced by cellular or nonspecific mitogenic stimuli. Blood 2002, 99:3838-3843.

56. Aggarwal S, Pittenger MF: Human mesenchymal stem cells modulate allogeneic immune cell responses. Blood 2005, 105: I8I5-1822.

57. Yu Q, Watson RR, Marchalonis JJ, Larson DF: A role for T lymphocytes in mediating cardiac diastolic function. Am J Physiol Heart Circ Physiol 2005, 289:H643-65I.

58. Ohnishi S, Sumiyoshi H, Kitamura S, Nagaya N: Mesenchymal stem cells attenuate cardiac fibroblast proliferation and collagen synthesis through paracrine actions. FEBS Lett 2007, 58I:396I-3966.

59. Iso $Y$, Spees JL, Serrano C, Bakondi B, Pochampally R, Song YH, Sobel $B E$, Delafontaine $P$, Prockop DJ: Multipotent human stromal cells improve cardiac function after myocardial infarction in mice without long-term engraftment. Biochem Biophys Res Commun 2007, 354:700-706.

60. Nagaya N, Kangawa K, Itoh T, Iwase T, Murakami S, Miyahara Y, Fujii T, Uematsu M, Ohgushi H, Yamagishi M, Tokudome T, Mori H, Miyatake K, Kitamura S: Transplantation of mesenchymal stem cells improves cardiac function in a rat model of dilated cardiomyopathy. Circulation 2005, I | 2: I | 28- I | 35 .
61. Nakamura T, Matsumoto K, Mizuno S, Sawa Y, Matsuda H: Hepatocyte growth factor prevents tissue fibrosis, remodeling, and dysfunction in cardiomyopathic hamster hearts. Am J Physiol Heart Circ Physiol 2005, 288:H2 I 3 I-2I39.

62. Nagaya N, Satoh T, Nishikimi T, Uematsu M, Furuichi S, Sakamaki F, Oya H, Kyotani S, Nakanishi N, Goto Y, Masuda Y, Miyatake K, Kangawa K: Hemodynamic, renal, and hormonal effects of adrenomedullin infusion in patients with congestive heart failure. Circulation 2000, 10 I:498-503.

63. Tsuruda T, Kato J, Kitamura K, Kawamoto M, Kuwasako K, Imamura T, Koiwaya $Y$, Tsuji T, Kangawa K, Eto T: An autocrine or a paracrine role of adrenomedullin in modulating cardiac fibroblast growth. Cardiovasc Res 1999, 43:958-967.

64. Cavasin MA: Therapeutic potential of thymosin-beta4 and its derivative $\mathbf{N}$-acetyl-seryl-aspartyl-lysyl-proline (Ac-SDKP) in cardiac healing after infarction. Am J Cardiovasc Drugs 2006, 6:305-31I.

65. Palmer JN, Hartogensis WE, Patten M, Fortuin FD, Long CS: Interleukin-I beta induces cardiac myocyte growth but inhibits cardiac fibroblast proliferation in culture. I Clin Invest 1995, 95:2555-2564.

66. Pasha Z, Wang Y, Sheikh R, Zhang D, Zhao T, Ashraf M: Preconditioning enhances cell survival and differentiation of stem cells during transplantation in infarcted myocardium. Cardiovasc Res 2008, 77: $134-142$.

67. Li TS, Hayashi M, Ito H, Furutani A, Murata T, Matsuzaki M, Hamano $\mathrm{K}$ : Regeneration of infarcted myocardium by intramyocardial implantation of ex vivo transforming growth factorbeta-preprogrammed bone marrow stem cells. Circulation 2005, II I:2438-2445.

68. Boomsma RA, Swaminathan PD, Geenen DL: Intravenously injected mesenchymal stem cells home to viable myocardium after coronary occlusion and preserve systolic function without altering infarct size. Int / Cardiol 2007, 122:17-28.

69. Wang X, Hu Q, Nakamura Y, Lee J, Zhang G, From AH, Zhang J: The role of the sca-I+/CD3 I- cardiac progenitor cell population in postinfarction left ventricular remodeling. Stem Cells 2006 24:1779-1788.

70. Zeng L, Hu Q, Wang X, Mansoor A, Lee J, Feygin J, Zhang G, Suntharalingam P, Boozer S, Mhashilkar A, Panetta C], Swingen C, Deans R, From AH, Bache RJ, Verfaillie CM, Zhang J: Bioenergetic and functional consequences of bone marrow-derived multipotent progenitor cell transplantation in hearts with postinfarction left ventricular remodeling. Circulation 2007, I I 5: I866-I875.

7I. Urbanek K, Rota M, Cascapera S, Bearzi C, Nascimbene A, De Angelis A, Hosoda T, Chimenti S, Baker M, Limana F, Nurzynska D, Torella D, Rotatori F, Rastaldo R, Musso E, Quaini F, Leri A, Kajstura J, Anversa P: Cardiac stem cells possess growth factor-receptor systems that after activation regenerate the infarcted myocardium, improving ventricular function and long-term survival. Circ Res 2005, 97:663-673.

72. Urbich C, Aicher A, Heeschen C, Dernbach E, Hofmann WK, Zeiher AM, Dimmeler S: Soluble factors released by endothelial progenitor cells promote migration of endothelial cells and cardiac resident progenitor cells. J Mol Cell Cardiol 2005, 39:733-742.

73. Gimble J, Guilak F: Adipose-derived adult stem cells: isolation, characterization, and differentiation potential. Cytotherapy 2003, 5:362-369.

74. Asakura $A$, Komaki M, Rudnicki M: Muscle satellite cells are multipotential stem cells that exhibit myogenic, osteogenic, and adipogenic differentiation. Differentiation 200I, 68:245-253.

75. Erices $A$, Conget $P$, Minguell JJ: Mesenchymal progenitor cells in human umbilical cord blood. Br J Haematol 2000, 109:235-242.

76. De Bari C, Dell'Accio F, Tylzanowski P, Luyten FP: Multipotent mesenchymal stem cells from adult human synovial membrane. Arthritis Rheum 2001, 44:1928-1942.

77. Nakahara H, Bruder SP, Goldberg VM, Caplan Al: In vivo osteochondrogenic potential of cultured cells derived from the periosteum. Clin Orthop Relat Res 1990:223-232.

78. Gronthos S, Mankani M, Brahim J, Robey PG, Shi S: Postnata human dental pulp stem cells (DPSCs) in vitro and in vivo. Proc Natl Acad Sci USA 2000, 97: I3625-13630.

79. Seo BM, Miura M, Gronthos S, Bartold PM, Batouli S, Brahim J, Young M, Robey PG, Wang CY, Shi S: Investigation of multipotent post- 
natal stem cells from human periodontal ligament. Lancet 2004, 364: I49-I55.

80. Fukuchi $Y$, Nakajima $H$, Sugiyama D, Hirose I, Kitamura T, Tsuji K: Human placenta-derived cells have mesenchymal stem/progenitor cell potential. Stem Cells 2004, 22:649-658.

81. da Silva Meirelles L, Chagastelles PC, Nardi NB: Mesenchymal stem cells reside in virtually all post-natal organs and tissues. J Cell Sci 2006, I I 9:2204-22 I3.

82. Kim Y, Kim H, Cho H, Bae Y, Suh K, Jung J: Direct comparison of human mesenchymal stem cells derived from adipose tissues and bone marrow in mediating neovascularization in response to vascular ischemia. Cell Physiol Biochem 2007, 20:867-876.

83. Rehman J, Traktuev D, Li J, Merfeld-Clauss S, Temm-Grove CJ, Bovenkerk JE, Pell CL, Johnstone BH, Considine RV, March KL: Secretion of angiogenic and antiapoptotic factors by human adipose stromal cells. Circulation 2004, 109:1292-1298.

84. Cai L, Johnstone BH, Cook TG, Liang Z, Traktuev D, Cornetta K, Ingram DA, Rosen ED, March KL: Suppression of hepatocyte growth factor production impairs the ability of adiposederived stem cells to promote ischemic tissue revascularization. Stem Cells 2007, 25:3234-3243.

85. Wang M, Tsai BM, Crisostomo PR, Meldrum DR: Pretreatment with adult progenitor cells improves recovery and decreases native myocardial proinflammatory signaling after ischemia. Shock 2006, 25:454-459.

86. Burchfield JS, Iwasaki M, Koyanagi M, Urbich C, Rosenthal N, Zeiher AM, Dimmeler S: Interleukin- 10 from transplanted bone marrow mononuclear cells contributes to cardiac protection after myocardial infarction. Circ Res 2008, 103:203-2 II.

Publish with Bio Med Central and every scientist can read your work free of charge

"BioMed Central will be the most significant development for disseminating the results of biomedical research in our lifetime. "

Sir Paul Nurse, Cancer Research UK

Your research papers will be:

- available free of charge to the entire biomedical community

- peer reviewed and published immediately upon acceptance

- cited in PubMed and archived on PubMed Central

- yours - you keep the copyright

Submit your manuscript here:

http://www.biomedcentral.com/info/publishing_adv.asp 